\title{
Ferroptosis: At the Crossroad of Gemcitabine Resistance and Tumorigenesis in Pancreatic Cancer
}

\author{
Jianhui Yang $1,2,3,4,+$, Jin Xu ${ }^{1,2,3,4,+}$, Bo Zhang $1,2,3,4,+$, Zhen Tan $1,2,3,4$, Qingcai Meng 1,2,3,4, Jie Hua 1,2,3,4, \\ Jiang Liu ${ }^{1,2,3,4}$, Wei Wang ${ }^{1,2,3,4}$, Si Shi ${ }^{1,2,3,4} \mathbb{D}$, Xianjun Yu 1,2,3,4,* and Chen Liang $1,2,3,4, *$
}

1 Department of Pancreatic Surgery, Fudan University Shanghai Cancer Center, Shanghai 200032, China; yangiianhui@fudanpci.org (J.Y.); xujin@fudanpci.org (J.X.); zhangbo@fudanpci.org (B.Z.); tanzhen@fudanpci.org (Z.T.); mengqingcai@fudanpci.org (Q.M.); huajie@fudanpci.org (J.H.); liujiang@fudanpci.org (J.L.); wangwei@fudanpci.org (W.W.); shisi@fudanpci.org (S.S.)

2 Department of Oncology, Shanghai Medical College, Fudan University, Shanghai 200032, China

3 Shanghai Pancreatic Cancer Institute, Shanghai 200032, China

4 Pancreatic Cancer Institute, Fudan University, Shanghai 200032, China

* Correspondence: yuxianjun@fudanpci.org (X.Y.); liangchen@fudanpci.org (C.L.); Tel.: +86-021-64175590 (X.Y.); +86-18818210694 (C.L.); Fax: +86-021-64031446 (X.Y.)

+ These authors contributed equally to this work.

check for updates

Citation: Yang, J.; Xu, J.; Zhang, B.; Tan, Z.; Meng, Q.; Hua, J.; Liu, J.; Wang, W.; Shi, S.; Yu, X.; et al. Ferroptosis: At the Crossroad of Gemcitabine Resistance and Tumorigenesis in Pancreatic Cancer Int. J. Mol. Sci. 2021, 22, 10944. https: / / doi.org/10.3390/ ijms222010944

Academic Editor: Nils Cordes

Received: 13 September 2021

Accepted: 5 October 2021

Published: 10 October 2021

Publisher's Note: MDPI stays neutral with regard to jurisdictional claims in published maps and institutional affiliations.

Copyright: (c) 2021 by the authors. Licensee MDPI, Basel, Switzerland. This article is an open access article distributed under the terms and conditions of the Creative Commons Attribution (CC BY) license (https:// creativecommons.org/licenses/by/ $4.0 /)$.

\begin{abstract}
The overall five-year survival rate of pancreatic cancer has hardly changed in the past few decades (less than $10 \%$ ) because of resistance to all known therapies, including chemotherapeutic drugs. In the past few decades, gemcitabine has been at the forefront of treatment for pancreatic ductal adenocarcinoma, but more strategies to combat drug resistance need to be explored. One promising possibility is ferroptosis, a form of a nonapoptotic cell death that depends on intracellular iron and occurs through the accumulation of lipid reactive oxygen species, which are significant in drug resistance. In this article, we reviewed gemcitabine-resistance mechanisms; assessed the relationship among ferroptosis, tumorigenesis and gemcitabine resistance, and explored a new treatment method for pancreatic cancer.
\end{abstract}

Keywords: ferroptosis; gemcitabine resistance; NRF2; ROS; pancreatic ductal adenocarcinoma

\section{Introduction}

Pancreatic cancer is a digestive tumor with high mortality and metastasis rates that still rank among the top-10 list medical challenges [1-4]. By 2030, because of the general aging of the population and improvements in other cancer treatments pancreatic cancer is expected to surpass breast, prostate, and colorectal cancer as the second-leading cause of cancer-related death in Western countries after lung cancer [5].

Ferroptosis is a form of cell death that is different from apoptosis, necroptosis, or autophagy [6]. It is characterized by lipid peroxidation and depends on intracellular iron and the accumulation of reactive oxygen species (ROS) [7,8]. It has been found in many pathological diseases, such as ischemia-reperfusion injury, neurodegenerative diseases, and in different cancer types (e.g., hepatocellular, breast and pancreatic) [8-10] It was discovered in a high-throughput screening campaign to identify molecules that can selectively induce cell death in isogenic cells carrying RAS mutant subtypes [11]. It was reported that Kirsten rat sarcoma virus oncogene (KRAS) mutations were present in approximately $95 \%$ of cases of pancreatic cancer and played an important role in its occurrence and development [12,13]. Therefore, there may be some special links between ferroptosis and the development of pancreatic cancer.

Pancreatic ductal adenocarcinoma (PDAC) is the primary pathological type of pancreatic cancer and has a poor prognosis [14]. Gemcitabine is the main chemotherapy treatment, but after a few weeks resistance begins to develop [15]; nevertheless, initial sensitivity of PDAC to gemcitabine provides patients with an opportunity for surgical treatment. 
Therefore, elucidating the molecular basis of gemcitabine resistance may help increase the effectiveness of this chemotherapy. At the same time, studies have shown that inhibiting cystine/glutamate antiporter (xCT) and glutathione peroxidase (GPX4) — key molecules related to ferroptosis-may be beneficial for inducing the clearance of cancer cells that are resistant to conventional chemo- or radiotherapy [16]. Therefore, it is particularly important to explore the relationship between ferroptosis and gemcitabine resistance not only for PDAC patients but also for those with, for example, biliary tract, breast or non-small cell lung cancer.

\section{Entanglement between Pancreatic Cancer and Gemcitabine Resistance}

\subsection{Rapidly Developing Tumors and Drug Resistance Make Pancreatic Cancer Difficult to Treat}

Surgery has so far increased the survival of pancreatic cancer patients. Unlike surgical methods in previous decades, which were highly risky and difficult, modern surgery in experienced centers is relatively safe $[12,17]$ but is only suitable for $15-20 \%$ of cases. In addition, the post-operative tumor recurrence is high, and the local recurrence rate exceeds $50 \%$. The randomized controlled trial showed that the 5-year survival rate of patients undergoing tumor resection is about $28 \%$, and the median survival time is 18 months. The above data indicate that surgery as a treatment has limits. [15]. Therefore, in the past few decades, adjuvant treatment strategies have gradually been developed to improve survival of which chemotherapy is an indispensable part. Adjuvant chemotherapy after radical surgery can significantly improve the survival rate and reduce recurrence [18]. Solid tumors have high interstitial tension and poor blood perfusion during growth. This is especially apparent in pancreatic cancer, which have a low blood supply and show abnormal resistance to most chemotherapy drugs. Conventional intravenous chemotherapy often fails to deliver effective amounts of drugs to the tumor. If the total dose is too high, adverse reactions may weaken the patient's immune system and reduce the drug's therapeutic effect. For decades, researchers have made progress in diagnosis, surgery, chemotherapy, immunotherapy, but the overall prognosis of PDAC patients is still poor [12,19].

\subsection{Variability of Drug Resistance in Pancreatic Cancer}

Pancreatic cancer is still one of the most challenging research fields despite continuing efforts to find an effective treatment [20,21] for disease progression [22]. Treatment failure is due to a variety of factors, including resistance to traditional chemotherapy, which can be classified as extrinsic and intrinsic resistance $[23,24]$. Gemcitabine is usually the recommended first-line drug for PDAC patients, and can be combined with other drugs to enhance the efficacy of the chemotherapy [25]. External resistance from the surrounding dense tumor stroma is easier to understand because it acts as a biophysical rampart that segregates PDAC into tumor epithelial cells inside the stroma and keeps chemotherapy drugs like gemcitabine outside [26]. However, the mechanism of intrinsic resistance to gemcitabine is still an active area of research [27].

Gemcitabine, a nucleoside analog of deoxycytidine, was approved by the FDA in 1996 and is now widely used in the treatment of various solid tumors (breast, ovarian cancer and non-small cell lung cancers [28]) and is still the cornerstone of neoadjuvant, adjuvant and palliative treatment of PDAC [29]. The cytotoxic activity of gemcitabine (2', $2^{\prime}$-difluoro $2^{\prime}$-deoxycytidine, $\mathrm{dFdC}$ ) is based on several effects on DNA synthesis. Due to the structural differences between the fluorine substituents at the $2^{\prime}$ position of the furanose ring, gemcitabine has obvious therapeutic advantages over other nucleotide analogs in terms of cellular pharmacology, metabolism and mechanism of action [28]. It has a rapid deamination effect on its inactive metabolite, $\mathrm{dFdU}$, and requires a series of phosphorylation steps to attain relevant activity. Therefore, gemcitabine has certain limitations as an alternative drug, especially due to its toxicity at high and repeated doses and the development of chemotherapy resistance [30].

Compared with other malignant tumors, the main histopathological feature of PDAC is the hyperplasia of the surrounding interstitium of the locally infiltrated tumor tissue, 
which distorts the normal structure of pancreatic tissue [31]. The pathological feature of PDAC is its dense fibroproliferative tumor matrix and the intertwined sparse and collapsed vasculature, which is conducive to the occurrence and development of drug-resistant phenotypes. The pancreatic cancer stroma is composed of cancer-associated fibroblasts (CAF), vasculature, extracellular matrix (ECM) and immune cells [32]. CAFs promote tumor development and drug resistance by regulating the microenvironment or directly regulating tumor epithelial cells [33]. Multiple studies have shown that the tumor stroma promotes tumor progression, invasion, metastasis and chemoresistance in PDAC [34]. Therefore, the PDAC matrix is also considered to be a factor affecting gemcitabine resistance. A large amount of evidence shows that the matrix affects the external resistance by impairing the delivery of gemcitabine [35]. At the same time, research on the matrix-mediated intrinsic resistance mechanism of gemcitabine has also been topical in recent years.

\subsection{Exploration of Some Pathways of Gemcitabine Resistance Related to Ferroptosis}

\subsubsection{PI3K/Akt Pathway and MAPK Pathway}

Pancreatic studies have shown that excessive activation of the PI3K/Akt pathway can lead to gemcitabine resistance [36]. This event was verified by taking several selective PI3K or Akt inhibitors (Figure 1). At the same time, these factors led to the recovery of Bax pool and gemcitabine-induced apoptosis [36-38]. Studies have shown that thymoquinone, an inhibitor of the Akt/mTOR/S6 pathway, not only enhances the sensitivity of oxaliplatin and cisplatin in pancreatic cancer but also similarly promotes sensitivity to gemcitabine [39]. Phosphatase and tensin homologue (PTEN), deleted on chromosome 10, is best characterized as an antagonist of the PI3K/Akt signaling pathway [40,41]. There is increasing evidence that upregulating PTEN helps increase the chemosensitivity of pancreatic cancer cells resistant to gemcitabine [42,43]. The Src tyrosine kinase pathway is another driver of the Akt pathway, and its role in PDAC is over-amplified by KRAS. $\mathrm{Src} / \mathrm{ErbB} 2$ induces Akt activation and gemcitabine resistance in pancreatic cancer through amplification cycles $[44,45]$, and apoptosis induced by the caspase signaling pathway is related to the MAPK pathway. The cytotoxic effect of gemcitabine may be mediated by the activation of p38, leading to MAPK-caspase-dependent apoptosis [46]. In recent years, studies have also found that ferroptosis is closely related to the MAPK pathway. The activation of STAT3 induced by ferroptosis inducer erastin in PDAC cells requires activation of the MAPK/ERK pathway [47]. Studies have also found that the ASK1-p38 MAPK pathway is one of the regulators of ferroptosis downstream of lipid peroxides [48]. Therefore, ferroptosis and gemcitabine resistance may also have a certain relationship in the PI3K/Akt and MAPK pathways.

\subsubsection{NF-KB and NRF2 Pathway}

Nuclear factor-K-gene binding (NF-KB) was up-regulated after gemcitabine treatment in colon cancer, breast cancer and PDAC [49-51]. Data showed that approximately 75\% of cases showed a loss of p53 function, and gemcitabine upregulated the level of NF-KB in a dose-dependent manner. Accordingly, inhibition of the NF-KB pathway in PDAC cells diminished gemcitabine resistance to varying degrees [52-54]. The research findings provided a combined strategy for regulating cell redox status and overcoming gemcitabine resistance, resulting in a synergistic and selective cytotoxic effect in vivo. Recent reports indicate that NF-KB and Nuclear factor erythroid-2-related factor 2 (NRF2) play an important role in the development of pancreatic cancer and chemoresistance [55]. The report described that gemcitabine activates NOX-induced ROS accumulation through NF-KB, and the increased ROS level can induce the activation of NRF2 and the increase of intracellular GSH, which leads to the intrinsic resistance of PDAC to gemcitabine. Gemcitabine stimulates the generation of endogenous ROS, and phenethyl isothiocyanate (PEITC) inhibits the elimination of ROS. The combination of the two induces strong oxidative stress, which in turn induces the death of pancreatic cancer cells [27]. 
NRF2 is a transcription factor that can regulate the expression of genes involved in cell protection and anti-oxidation, thereby protecting cells from electrophilic or oxidative stress [56]. In the cell, NRF2 can bind to the Kelch-like ECH-related protein 1 (Keap1) in the cytoplasm and be degraded by the E3 ubiquitin proteasome. Recent studies have also shown that NRF2 overexpression is involved in the cell proliferation and chemoresistance of various cancers [57-60]. The deficiency of HEAT repeat containing 1(HEATR1) can promote pancreatic cancer proliferation and gemcitabine resistance by up-regulating NRF2 signal. Digoxin reverses gemcitabine resistance by inhibiting the NRF2 signal in SW1990/GEM and Panc-1/GEM cells [61,62]. Some researchers have used experiments at the level of related genes to prove that after PDAC cells are treated with gemcitabine additional NRF2 depletion reduces GSH levels and increases ROS production. In addition, knockdown of NRF2 with NRF2 siRNA found that cell lines with different PDACs were more sensitive to gemcitabine [27]. In addition, some researchers used PIK-75 to inhibit NRF2 and changed the sensitivity of pancreatic cancer cells to gemcitabine [63]. Studies also showed that reducing the glutathione pool to promote the redox regulation mechanism induced by gemcitabine may affect tumor cell survival and drug sensitivity. In addition, it was found that PEITC can consume GSH and subsequently strengthen the oxidative stress response $[64,65]$, which may affect this pathway to enhance the sensitivity of gemcitabine to pancreatic cancer. Hence, NRF2 has a great clinical application value in gemcitabine resistance.

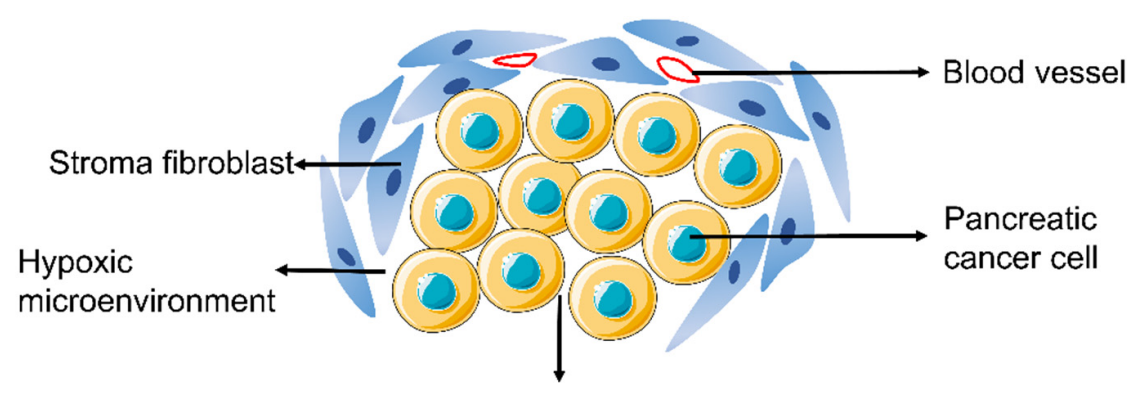

Deregulated signal pathways

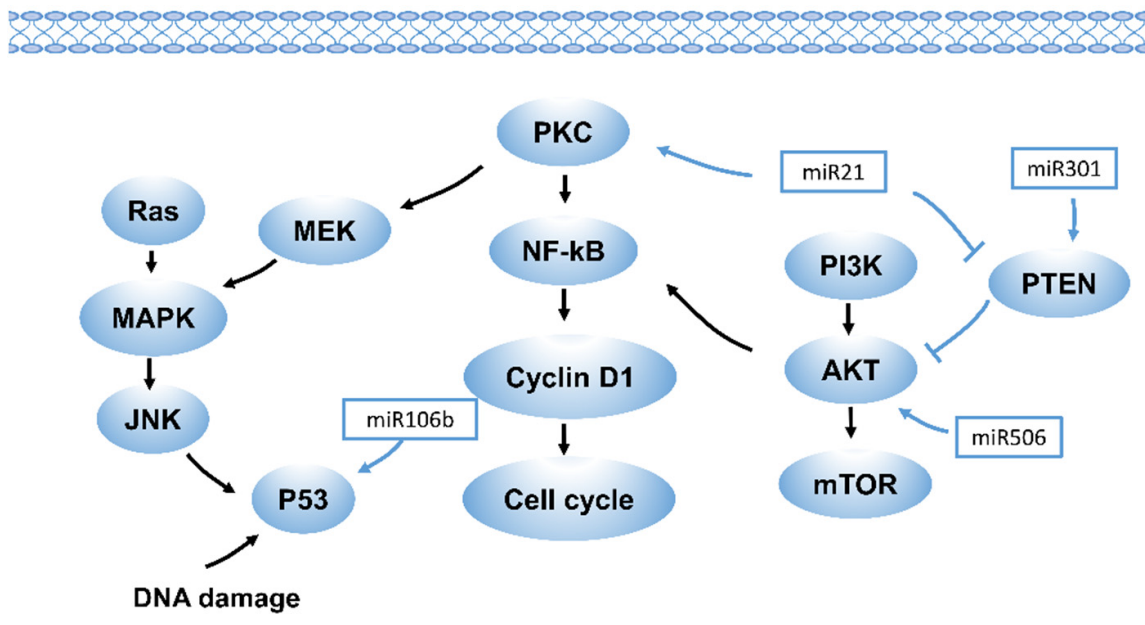

Figure 1. Drug resistance pathways in pancreatic cancer. RAS, rat sarcoma virus oncogene; JNK, Jun N-terminal kinase; NF-KB, nuclear factor-K-gene binding; PKC, Protein kinase C; PTEN, phosphatase and tensin homologue; PI3K, phosphatidylinositol 3-kinase. Drug resistance in pancreatic cancer is caused by various mechanisms, including aberrant gene expression, mutations, and deregulation of key signaling pathways (such as MAPK, Akt, NF-KB, and miRNA-related pathways). Each of these pathways contributes to drug resistance in pancreatic cancer in different ways, which suggests that different therapeutic targets exist. A few representative drug resistance pathways are shown, such as the MAPK, Akt, NF-KB, and miRNA-related pathways. 


\subsubsection{HSP Pathway}

Heat shock proteins (HSP) are a group of highly conserved proteins that belong to the class of molecular chaperones and are induced by different kinds of stress [66]. It has strong cell protection properties and can regulate the response of cells to various stresses. Some HSPs can produce cell protection against chemotherapy and other attacks, and some can drive gemcitabine-induced apoptosis. Heat shock transcription factor (HSF) can be regulated by HSP90, HSP70 and HSP27. Compared with normal tissues, it is overexpressed in several malignant tumors [29]. The data suggest that HSP90 inhibition is a highly effective therapeutic strategy in pancreatic cancer supported by its ability to inhibit antiapoptotic and proliferative pathways by synchronously interrupting multiple key oncogenic signaling cascades in gemcitabine and 5-FU-resistant pancreatic cancer [67]. Overexpression of HSP70 in sarcoma cells induces gemcitabine resistance, and modulation of HSP70 expression with quercetin (an HSF inhibitor) enhances the chemo-responsiveness of pancreatic cancer cells to gemcitabine [68,69]. In addition, when HSP27 was knocked down in resistant pancreatic cells (KLM1-R), sensitivity to gemcitabine was restored. In addition, the increased expression of HSP27 in tumor tissues was related to gemcitabine resistance in patients with pancreatic cancer [70]. Interestingly, when studying the highthroughput liquid chromatography-tandem mass spectrometry (LC/MS) assay to detect the drug resistance pattern in PDAC cells, it was found that HSP27 and nucleophosmin are closely related to gemcitabine resistance [71,72]. These results may suggest that HSPs play an important role in resistance to gemcitabine.

\subsection{4. miRNA-Related Pathway}

MicroRNAs (miRNAs) are short non-coding RNAs with a length of 18-22 nucleotides, which are related to cell proliferation, cell cycle control, cell differentiation, migration, invasion, and chemotherapy resistance [73,74]. According to research, miRNAs are thought to have a regulatory role in pancreatic cancer resistance to gemcitabine and regulate related pathways such as KRAS, PI3K-AKT, NF-kB, P53, and Hedgehog [75]. MiR-21 expression is directly correlated with chemotherapy resistance and promotes gemcitabine resistance by targeting PTEN or by overexpressing matrix metalloproteinase 2 (MMP2), matrix metalloproteinase 9 (MMP9) and vascular endothelial growth factor (VEGF), which in turn induces the PI3K/AKT pathway. MiR-301a-3p confers resistance to gemcitabine by regulating the expression of PTEN [76]. Some miRNAs have also been found to be involved in the inhibition of gemcitabine-induced apoptosis. Pretreatment of CAFs with miR-106b inhibited their expression in CAF exosomes, thereby reducing gemcitabine resistance. In-depth research found that miR-106b promotes gemcitabine resistance of cancer cells by directly targeting TP53INP1 [77]. In addition, exosomal miR-222-3p can regulate gemcitabine resistance and maintain the malignant characteristics of pancreatic cancer by targeting SOCS3 [78]. Studies also found that the overexpression of miR-365 in aggressive PDAC can directly lead to gemcitabine resistance (Figure 1). It may affect the adaptor protein Src homology 2 domain contains 1 (SHC1) and the apoptosis-promoting gene Bax [79]. In addition, the overexpression of miR-200 that was concomitant with gemcitabine treatment reversed resistance [80]. MiR-506 enhanced apoptosis and chemosensitivity of pancreatic cancer cells by SPHK1/Akt/NF-KB signaling [81].

\section{Ferroptosis Promotes Tumorigenesis in Pancreatic Cancer}

Ferroptosis is a regulated form of cell death, mainly caused by the loss of activity of the lipid repair enzyme glutathione peroxidase 4 (GPX4) and the accumulation of lipid-based ROS, especially lipid hydroperoxide [6]. Studies have shown that the pathways involved in ferroptosis include iron metabolism and ROS metabolism pathways [16,82]. Morphologically, it was found that during ferroptosis, the volume of mitochondria decreased; the density of mitochondrial membrane increased; the mitochondrial ridges disappeared; and the outer membrane ruptured [83]. 
Iron metabolism in cells includes iron input, storage and output. After binding to transferrin, ferric iron $\left(\mathrm{Fe}^{3+}\right)$ is transported to the endosome through transferrin receptor 1, and then is reduced to ferrous iron $\left(\mathrm{Fe}^{2+}\right)$, and finally accumulates in the unstable iron pool in the cytoplasm. Cytoplasmic iron is mainly ferritin $(\mathrm{Ft})$ : heavy chain $(\mathrm{FtH})$ and light chain (FtL). Finally, the excess iron is exported by an iron transporter. Compared with drug-sensitive cells, the uptake, storage and output of iron in drug-resistant cancer cells have changed a little $[84,85]$. In research about the relationship between iron metabolism and tumors, it was found that cancer cells have a large demand for iron, and iron promotes the formation and metastasis of tumor cells [86-88].

ROS belong to partially reduced oxygen-containing molecules, including superoxide $\left(\mathrm{O}_{2} \bullet-\right)$, peroxide $\left(\mathrm{H}_{2} \mathrm{O}_{2}\right.$ and $\left.\mathrm{ROOH}\right)$ and free radicals ( $\mathrm{HO} \bullet$ and $\left.\mathrm{RO} \bullet\right)$. Iron participates in the Fenton reaction in which $\mathrm{Fe}^{2+}$ reacts with hydrogen peroxide [85] generating hydroxyl radicals, another ROS. The mitochondria in the cell generates a large amount of ROS through normal metabolism in the electron transport chain and energy production [89]. ROS from ferroptosis can reduce the stability of DNA thereby promoting cancer cell death.

In the high-throughput screening of small molecule libraries, it was found that erastin and RAS selective lethal small molecule 3 (RSL3) can be used as ferroptosis-inducing compounds and cause oncogenic RAS mutant cells to be selectively lethal without inducing apoptosis $[11,90]$. Several molecules that regulate iron metabolism and lipid peroxidation have recently been discovered. Among them, system Xc- and GPX4 are negative regulators of ferroptosis [91]. After the cells are treated with erastin, the input of radiolabeled cystine (a substrate of the $X_{c}$-antiporter system) can be prevented, thus confirming that erastin inhibits the $X_{c-}$ system from activating ferroptosis [8]. In addition, knocking down GPX4 can generate more lipid ROS and induce ferroptosis. This further proves that RSL3 induces ferroptosis by inhibiting GPX4 [92], which is not affected by oxidized polyunsaturated fatty acids (PUFAs) or fatty-acid free radicals. The overall survival analysis found that the high expression of GPX4 was associated with the increased survival of PDAC patients. All these indicated that GPX4 may be the main prognostic marker of PDAC [93]. Studies also found that the Xc-SLC7A11 cystine-glutamate antiporter system affects the intracellular level of the cofactor glutathione (GSH) of GPX4. It was also found that drugs such as sulfasalazine, sorafenib or glutamate can inhibit related transporters to induce ferroptosis [94].

In recent years, researchers have invented the engineered mouse model (GEMM) of PDAC [95]. Compared with the normal model, GEEM has KRAS mutations or other changes in tumor suppressor genes (such as $p 53$ or $C d k n 2 a$ ) in mice. Although they have their own characteristics, there is no clinical pathology that can fully mimic PDAC. GEMM mainly includes two basic models: one is $\mathrm{Pdx1}-\mathrm{Cre} ; \mathrm{Kras}{ }^{\mathrm{G} 12 \mathrm{D} /+}$ mice (called KC), and the other is $\mathrm{Pdx1-Cre;} \mathrm{Kras}{ }^{\mathrm{G} 12 \mathrm{D} /+} ; \mathrm{T} p 53^{\mathrm{R} 172 \mathrm{H} /+}$ mice (called $\mathrm{KPC}$ ). This model is widely used to study the signal, mechanism and treatment strategy of PDAC. Studies have found that the histopathological progress of KPC is faster than that of KC, especially for poor vascular distribution, fibrosis, local infiltration and metastatic dissemination [83]. The study noted that in KC mice with extra GPX4 depletion or a high-iron diet, the application of the iron death inhibitor lipoxstatin-1 can prevent the death of KRAS-driven mice and change the pathological and molecular changes that the pancreas prevents [93]. The depletion of pancreas SLC7A11 in KPC mice (compared to KC mice, which lacks mutant TP53) will produce different phenotypes, and the induction of iron death will prevent mutant KRAS/Tp53induced pancreatic tumorigenesis [96]. Experimental studies have clarified the relevant mechanism. Oxidized nucleobases released from a high-iron diet or GPX4 consumption can induce the activation of transmembrane protein 173 (TMEM173, also known as STING) which is related to DNA sensor pathways. It can promote infiltration and activation of macrophages to cause the occurrence and development of pancreatic cancer [93] (Figure 2). GPX4 depletion or high-iron diet can induce iron death, and also increase the production and release of oxidized nucleobases (such as 8-OHG), which in turn promotes the accumulation and activation of macrophages, and produces abnormal cytokines, especially IL-6 and NOS2. Both are important participants in the development stage of PDAC and are 
associated with the low survival rate of pancreatic cancer [97]. A new discovery also indicates that zalcitabine, an antiviral drug for human immunodeficiency virus infection, can suppress the growth of primary and immortalized human pancreatic cancer cells through the induction of ferroptosis $[98,99]$. It relies on zalcitabine-induced mitochondrial DNA stress, which activates the STING1/TMEM173-mediated DNA sensing pathway. Moreover, researchers found that it promotes ferroptosis in human pancreatic cancer cell lines by increasing MFN1/2-dependent mitochondrial fusion [99]. At the same time, the study showed that ferroptosis could be triggered by inhibiting cystine import, GSH synthesis, or GPX4 in synergy with GOT1(cytosolic aspartate aminotransaminase) [100]. These verify the significance of ferroptosis in pancreatic cancer.

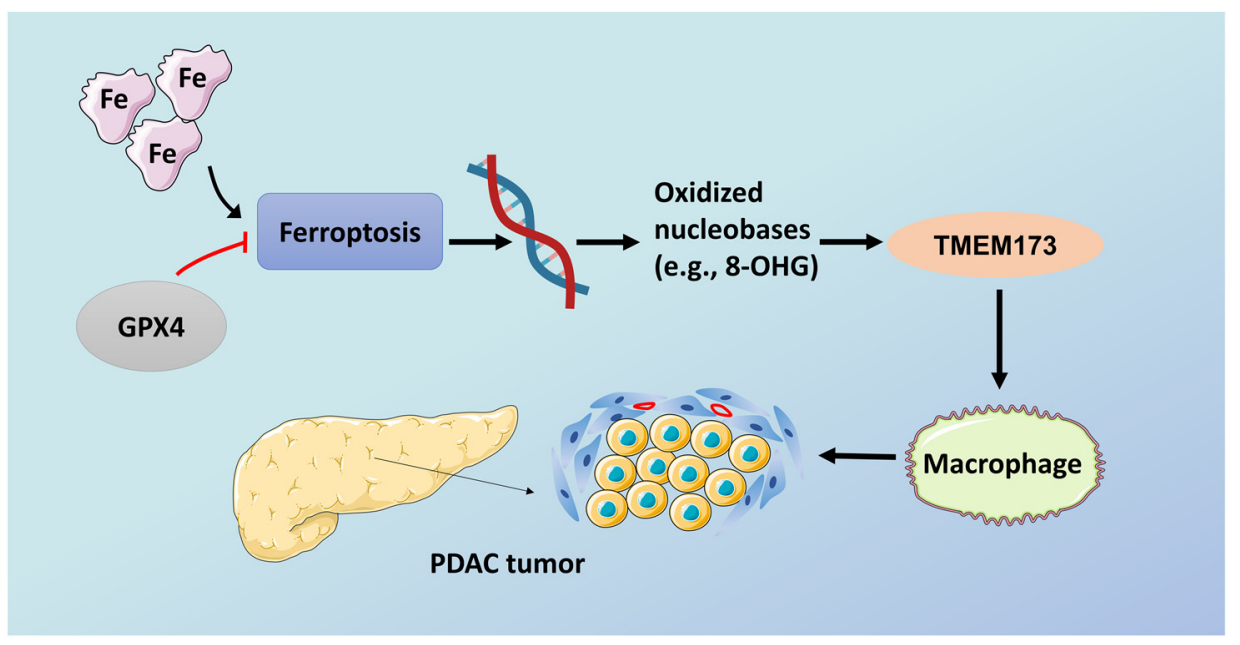

Figure 2. Ferroptosis promotes tumorigenesis in pancreatic cancer. GPX4, glutathione peroxidase 4; TMEM173, transmembrane protein 173. Schematic depicting the role of high-iron diets or GPX4 depletion in Kras-driven PDAC. The induction of ferroptosis by either high-iron diets or GPX4 depletion promotes oxidized nucleobase (e.g., 8-OHG) release and thus activates the TMEM173-dependent DNA sensor pathway, which finally results in macrophage infiltration and activation during Krasdriven PDAC. Consequently, macrophage depletion or pharmacological and genetic inhibition of the 8-OHG-TMEM173 pathway suppresses ferroptosis-mediated pancreatic tumorigenesis. The red line means the overexpression of GPX4 can inhibit the progression of ferroptosis.

\section{Induction of Ferroptosis Can Inhibit Gemcitabine Resistance}

Ferroptosis has been found to play a role in different cancers, including head and neck, and pancreatic cancer and hepatocellular carcinoma. Metallothionein (MT)-1G is a key regulator of sorafenib resistance in human hepatocellular carcinoma (HCC) cells. The knockout of MT-1G by RNA interference technology will increase glutathione consumption and lipid overexpression. Oxidation, which induces ferroptosis and affects the drug sensitivity of sorafenib, has a certain effect on preventing the development of the disease [101]. These experiments proved the new molecular mechanism of sorafenib resistance and indicated that MT-1G may be a new regulator of ferroptosis in HCC cells [102-104]. Studies also showed that inducing ferroptosis can overcome cisplatin resistance in head and neck cancer (HNC). These findings indicate that ferroptosis in HNC cells involves cell death mechanisms related to cystine, glutamine, iron, glutathione and ROS [105,106]. Therefore, ferroptosis may also play a role in gemcitabine resistance in pancreatic cancer cells (Figure 3). 


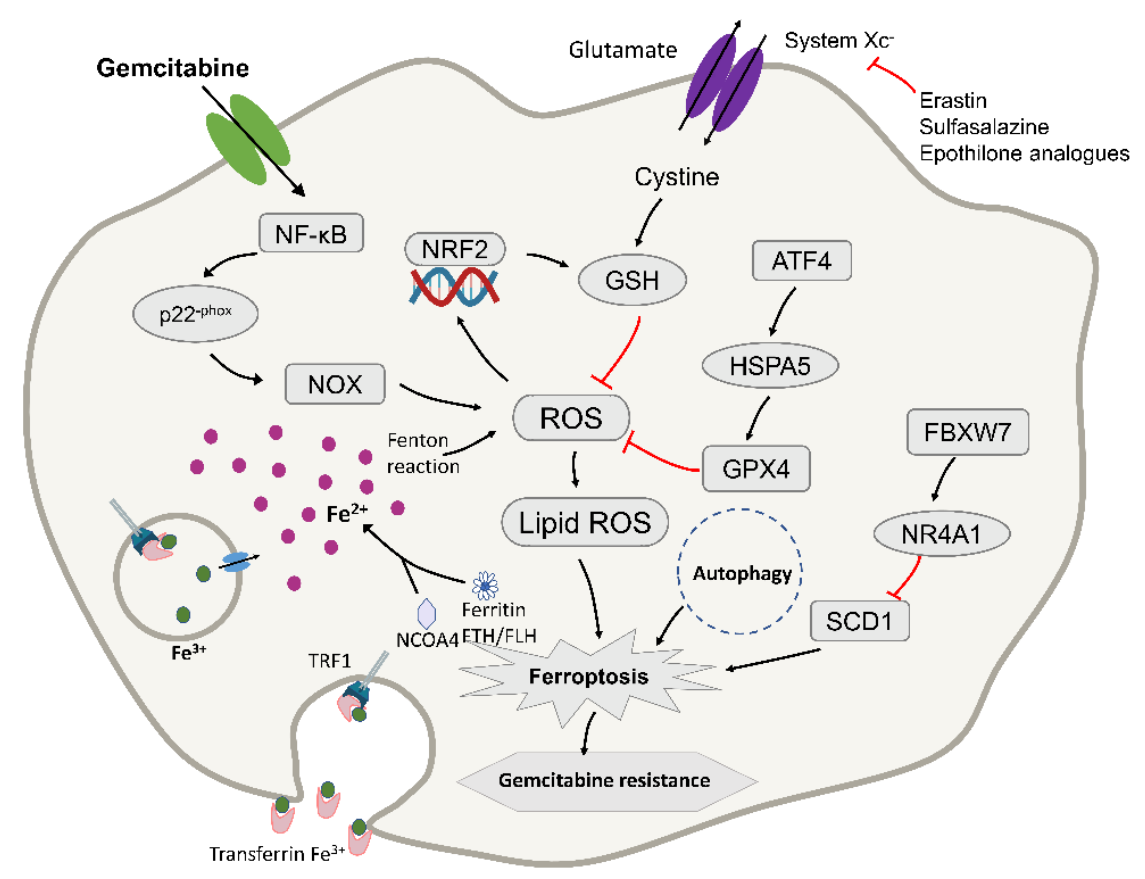

Figure 3. Diagram depicting the molecular targets of ferroptosis and gemcitabine in pancreatic cancer cells. TFR1, transferrin receptor 1; NRF2, nuclear factor erythroid 2-related factor 2; ROS, reactive oxygen species; GPX4, glutathione peroxidase-4; FtH/FtL, ferritin heavy chain/ferritin light chain; NCOA4, nuclear receptor coactivator 4. ATF4, activating transcription factor 4; HSPA5, Heat Shock Protein Family A (Hsp70) Member 5; FBXW7, F-box and WD repeat domain-containing 7; NR4A1, receptor subfamily 4 group A member 1 ; SCD1, stearoyl-CoA desaturase. ROS accumulation results in the activation of NRF2 and an increase in cellular GSH levels, contributing to intrinsic resistance in PDAC. It may to fight pancreatic cancer cells by inducing ferroptosis. The red lines mean that the expression of upstream molecules can inhibit the progress of downstream molecules.

\subsection{ROS at the Crossroad of Ferroptosis and Gemcitabine Resistance}

Gemcitabine induces the accumulation of ROS during treatment, which is a newly discovered cytotoxic mechanism aimed at revealing the mechanism of its intrinsic drug resistance, which has also been a prominent topic of research in recent years [27]. Gemcitabine can induce the production of ROS, which is an additional anti-cancer mechanism [54,107]. Excessive production of ROS can cause cell damage and eventually cell death. Therefore, in the process of continuous cell evolution, the cell develops a highly self-regulated antioxidant defense system to combat oxidative damage. The antioxidant system for ROS in the cell is composed of various antioxidant enzymes, including the enzyme that produces glutathione (GSH), glutamate cysteine ligase (GCL), and glutathione reductase (GSR) And glutathione S-transferase (GST). [108,109]. Most of these enzymes are regulated by the transcription factor NRF2 [110]. Studies have found that gemcitabine induces GSH synthesis by activating NRF2 to promote ROS detoxification, and consumption of NRF2 can enhance the sensitivity of PDAC cells to gemcitabine (Figure 3). An in-depth study of related mechanisms found that gemcitabine treatment induced NF-KB activation and NOX-derived ROS accumulation through p22-phox expression in PDAC cells [111]. As a feedback mechanism, nuclear translocation of NRF2 stimulated the transcription of protective antioxidant genes, mainly those that encode enzymes to catalyze the production of glutathione (GSH) to reduce ROS levels, thereby resisting gemcitabine treatment. For further verification, the use of RNA interference (RNAi)-mediated NRF2 consumption or $\beta$-phenethyl isothiocyanate inhibits the detoxification process of ROS by reducing GSH levels, thereby improving the efficacy of gemcitabine in vitro and in vivo [112]. Therefore, when gemcitabine is used for treatment, it induces the production of ROS and may further activate the oxygen pathway to induce ferroptosis. 


\subsection{A Key Molecule between Ferroptosis and Gemcitabine Resistance}

NRF2 is a major player in the regulation of antioxidant molecules in cells [113]. Indeed, it is an oncogenic transcription factor that plays a very important role in combating environmental or intracellular pressure and is responsible for regulating the cellular antioxidant system that produces GSH in cancer cells [114]. The data shows that most cancer cells show overexpression of NRF2, which is related to the poor effect of anti-cancer therapy and the low survival cycle of cancer patients. Interestingly, studies have found that the level of NRF2 in cells is closely related to the sensitivity of ferroptosis. Increased expression of NRF2 can prevent it, while decreased expression of NRF2 can enhance the sensitivity of cancer cells to iron death inducers $[102,115,116]$. Baicalein is a molecule found in some traditional Chinese herbal medicines and has powerful anti-cancer activity [117]. Baicalein showed higher anti-cancer activity in the ferroptosis of pancreatic cancer cells induced by erastin [118]. NRF2 positively regulates the key protein of ferroptosis, and can promote the transcription of its downstream targets, such as SLC7A11, G6PD and FTH176 [119]. These genes are involved in lipid peroxidation and iron metabolism and negatively regulate ferroptosis after transcription activation. Studies have shown that inhibiting the p62-Keap1-NRF2 pathway can significantly enhance the anti-cancer activity of erastin and sorafenib in HCC cells [102]. The research also demonstrated that plasma-treated, water-derived oxidants sensitize pancreatic cancer cells to ferroptotic cell death by targeting a NRF2-HMOX1-GPX4 specific kinase signaling network [120]. The above shows that NRF2 inhibitors and their downstream targets may be viable targets for inducing ferroptosis-dependent cancer cell death; in addition, they may also enhance the sensitivity of PDAC to gemcitabine. NRF2 inhibitors combined with ferroptosis inducers may be a feasible strategy for killing gemcitabine-resistant cells.

\subsection{HSPA5 Regulates Ferroptosis to Inhibit Gemcitabine Resistance in Pancreatic Cancer}

According to the molecular weight, HSPs can be divided into six families: HSP100, HSP90, HSP70, HSP60, HSP40 and small HSPs. HSP $\beta-1$ is a negative regulator of ferroptosis, and its inhibited expression and phosphorylation enhanced erastin-induced ferroptosis in human xenograft mouse tumor models [121,122].

Heat Shock Protein Family A (Hsp70) Member 5 (HSPA5, also termed GRP78 or BIP) is a molecular chaperone protein mainly expressed in the endoplasmic reticulum, with a size of approximately $70 \mathrm{kDa}$ [123]. As an important part of the unfolded protein response, HSPA5 can promote cell survival under endoplasmic reticulum stress conditions [124]. Recent reports clarified that upregulation of HSPA5 is a negative regulator of PDAC cell ferroptosis, prevents the degradation of GPX4, and inhibits lipid peroxidation during ferroptosis. Due to the low overall survival rate of PDAC, there are few other drug treatments for patients who have failed with gemcitabine. Studies found that when it is used in combination with HSPA5 inhibitors to treat PDAC, its anti-cancer activity is significantly increased, which is achieved by inducing ferroptosis [125]. At the same time, the increase in HSPA5 expression is closely related to the poor prognosis of PDAC patients [126]. Activating transcription factor 4 (ATF4) resulted in the induction of HSPA5, which in turn bound glutathione peroxidase 4 (GPX4) and protected against GPX4 protein degradation and subsequent lipid peroxidation. From this mechanism, this study showed that the upregulation of the HSPA5-GPX4 pathway contributed to gemcitabine resistance (Figure 3). In contrast, the use of RNAi, EGCG, or sulfasalazine to inhibit the genetic and pharmacological properties of the HSPA5-GPX4 pathway enhanced gemcitabine sensitivity in PDAC cells in vitro and mouse pancreatic cancer animal models [125]. These findings not only indicate the new role for HSPA5 in tumor ferroptosis, but also proposed a potential therapeutic strategy to overcome gemcitabine resistance in PDAC cells by inducing ferroptosis. 


\subsection{FBXW7 Potentiates Cytotoxic Effect of Gemcitabine via Ferroptosis}

It has been reported that the use of erastin to induce the iron death pathway can enhance the cytotoxic effects of gemcitabine and cisplatin on pancreatic cancer cells [127]. The study also confirmed that the ferroptosis inducer RSL3 also increased the cell killing effect of gemcitabine in pancreatic cancer cells, while the ferroptosis inhibitor Fer-1 had the opposite effect. These experiments confirmed that the induction of ferroptosis can enhance the sensitivity of gemcitabine to pancreatic cancer cells and reduce its drug resistance. Studies tested an enzyme called FBXW7 (F-box and WD repeat domain-containing 7) to affect the sensitivity of gemcitabine [128]. FBXW7 can promote ferroptosis and cell apoptosis, and it is speculated that it may affect the cytotoxicity of gemcitabine through iron death and cell apoptosis. They used the iron death inhibitor Fer-1 and the apoptosis inhibitor zVAD to treat FBXW7 overexpressing cells, and found that the two treatments separately or in combination counteracted the effect of FBXW7 overexpression on gemcitabine. Therefore, it was confirmed that FBXW7 enhanced the cytotoxic effect of gemcitabine through ferroptosis and apoptosis (Figure 3), and that this effect was achieved through the FBXW7-NR4A1-SCD1 pathway [129]. Moreover, short-hairpin RNA-based knockdown of SCD1 enhanced erastin-induced ferroptosis in vitro under H/NS (Hypoxia and nutrient starvation) [130]. Furthermore, this provided direction for new treatment methods. It also pointed out the way for future research; that is, the drug resistance of gemcitabine can be studied through the ferroptosis pathway [128].

\section{Conclusions and Perspectives}

Ferroptosis has gradually become one of the key research topics in recent years and has important biological significance in the treatment of related diseases. Pancreatic cancer is one of the tumors with a higher mortality rate, and drug chemotherapy is an important treatment strategy. Data in the literature show that for pancreatic cancer, induction of ferroptosis combined with gemcitabine therapy had a very good effect.

Inhibiting key molecules in the ferroptosis pathway, such as cystine/glutamate antiporter (xCT) and glutathione peroxidase (GPX4), can eliminate cancers that are resistant to conventional chemo- or radiotherapy. For example, multiple experiments confirmed that inhibiting the HSPA5-GPX4 pathway will enhance the sensitivity of gemcitabine in PDAC cells [125]. It was also demonstrated that the use of drugs to inhibit the system $\mathrm{x}_{\mathrm{c}^{-}}$can enhance the cytotoxic effects of gemcitabine and cisplatin in PDAC cell lines [127]. Kenneth P. Olive et al. also confirmed that, after using KPC mice to induce ferroptosis, pancreatic cancer cells needed exogenous cystine to avoid ferroptosis and the loss of the previous SLC7A11 subunit to prolonging survival [96]. At the same time, because gemcitabine activates NOX-induced ROS accumulation through NF-KB activation, the increased ROS level led to the activation of NRF2 and the increase of cellular GSH, which led to the inherent resistance of PDAC. NRF2 inhibition combined with ferroptosis induction may be effective against gemcitabine resistance in PDAC. At the same time, many new technologies have been applied to treat tumors. For example, some researchers applied an intriguing nanomedicine strategy to achieve autophagy-enhanced ferroptosis to combat cancer [131].

Therefore, combining the above methods to induce ferroptosis in PDAC cells may become a research direction to reverse the resistance to gemcitabine and may provide a reasonable basis for the development of new therapies for pancreatic cancer. It is believed that in the near future, effective treatment with a combination of drugs will become a reality, and researchers will develop more strategies to combat cancer.

Author Contributions: J.Y., S.S., B.Z., Z.T., Q.M., J.H., J.L., W.W. and J.X. gathered the literature and wrote the manuscript. C.L. and X.Y. designed the review and wrote the manuscript. All authors have read and agreed to the published version of the manuscript. 
Funding: This study was jointly funded by the national natural Science Foundation of China (No. 81902428, 81802352 and 81772555), the Shanghai Sailing Program (No. 19YF1409400), the national Science Foundation for Distinguished Young Scholars of China (No. 81625016), Clinical and Scientific Innovation Project of Shanghai Hospital Development Center (SHDC12018109) and Scientific Innovation Project of Shanghai Education Committee (2019-01-07-00-07-E00057) and Clinical Research Plan of Shanghai Hospital Development Center (SHDC2020CR1006A).

Institutional Review Board Statement: Not applicable.

Informed Consent Statement: Not applicable.

Data Availability Statement: Not applicable.

Acknowledgments: We are grateful to the editors of AJE (American Journal Experts) for their help in editing the manuscript.

Conflicts of Interest: The authors declare no conflict of interest.

\section{References}

1. Raimondi, S.; Maisonneuve, P.; Lowenfels, A.B. Epidemiology of pancreatic cancer: An overview. Nat. Rev. Gastroenterol. Hepatol. 2009, 6, 699-708. [CrossRef]

2. Ferlay, J.; Colombet, M.; Soerjomataram, I.; Dyba, T.; Randi, G.; Bettio, M.; Gavin, A.; Visser, O.; Bray, F. Cancer incidence and mortality patterns in Europe: Estimates for 40 countries and 25 major cancers in 2018. Eur. J. Cancer 2018, 103, 356-387. [CrossRef]

3. Ilic, M.; Ilic, I. Epidemiology of pancreatic cancer. World J. Gastroenterol. 2016, 22, 9694-9705. [CrossRef] [PubMed]

4. Kleeff, J.; Korc, M.; Apte, M.; La Vecchia, C.; Johnson, C.D.; Biankin, A.V.; Neale, R.E.; Tempero, M.; Tuveson, D.A.; Hruban, R.H.; et al. Pancreatic cancer. Nat. Rev. Dis. Primers 2016, 2, 16022. [CrossRef] [PubMed]

5. Rahib, L.; Smith, B.D.; Aizenberg, R.; Rosenzweig, A.B.; Fleshman, J.M.; Matrisian, L.M. Projecting cancer incidence and deaths to 2030: The unexpected burden of thyroid, liver, and pancreas cancers in the United States. Cancer Res. 2014, 74, $2913-2921$. [CrossRef] [PubMed]

6. Dixon, S.J.; Lemberg, K.M.; Lamprecht, M.R.; Skouta, R.; Zaitsev, E.M.; Gleason, C.E.; Patel, D.N.; Bauer, A.J.; Cantley, A.M.; Yang, W.S.; et al. Ferroptosis: An iron-dependent form of nonapoptotic cell death. Cell 2012, 149, 1060-1072. [CrossRef] [PubMed]

7. Yang, W.S.; Stockwell, B.R. Ferroptosis: Death by Lipid Peroxidation. Trends Cell Biol. 2016, 26, 165-176. [CrossRef] [PubMed]

8. Linkermann, A.; Skouta, R.; Himmerkus, N.; Mulay, S.R.; Dewitz, C.; De Zen, F.; Prokai, A.; Zuchtriegel, G.; Krombach, F.; Welz, P.S.; et al. Synchronized renal tubular cell death involves ferroptosis. Proc. Natl. Acad. Sci. USA 2014, 111, 16836-16841. [CrossRef] [PubMed]

9. Do Van, B.; Gouel, F.; Jonneaux, A.; Timmerman, K.; Gelé, P.; Pétrault, M.; Bastide, M.; Laloux, C.; Moreau, C.; Bordet, R.; et al. Ferroptosis, a newly characterized form of cell death in Parkinson's disease that is regulated by PKC. Neurobiol. Dis. 2016, 94, 169-178. [CrossRef]

10. Lu, B.; Chen, X.B.; Ying, M.D.; He, Q.J.; Cao, J.; Yang, B. The Role of Ferroptosis in Cancer Development and Treatment Response. Front. Pharmacol. 2017, 8, 992. [CrossRef]

11. Yang, W.S.; Stockwell, B.R. Synthetic lethal screening identifies compounds activating iron-dependent, nonapoptotic cell death in oncogenic-RAS-harboring cancer cells. Chem. Biol. 2008, 15, 234-245. [CrossRef] [PubMed]

12. Kamisawa, T.; Wood, L.D.; Itoi, T.; Takaori, K. Pancreatic cancer. Lancet 2016, 388, 73-85. [CrossRef]

13. Makohon-Moore, A.; Iacobuzio-Donahue, C.A. Pancreatic cancer biology and genetics from an evolutionary perspective. Nat. Rev. Cancer 2016, 16, 553-565. [CrossRef] [PubMed]

14. Bosetti, C.; Bertuccio, P.; Negri, E.; La Vecchia, C.; Zeegers, M.P.; Boffetta, P. Pancreatic cancer: Overview of descriptive epidemiology. Mol. Carcinog. 2012, 51,3-13. [CrossRef] [PubMed]

15. Neoptolemos, J.P.; Kleeff, J.; Michl, P.; Costello, E.; Greenhalf, W.; Palmer, D.H. Therapeutic developments in pancreatic cancer: Current and future perspectives. Nat. Rev. Gastroenterol. Hepatol. 2018, 15, 333-348. [CrossRef]

16. Xie, Y.; Hou, W.; Song, X.; Yu, Y.; Huang, J.; Sun, X.; Kang, R.; Tang, D. Ferroptosis: Process and function. Cell Death Differ. 2016, 23, 369-379. [CrossRef]

17. Hartwig, W.; Werner, J.; Jäger, D.; Debus, J.; Büchler, M.W. Improvement of surgical results for pancreatic cancer. Lancet Oncol. 2013, 14, e476-e485. [CrossRef]

18. Springfeld, C.; Jäger, D.; Büchler, M.W.; Strobel, O.; Hackert, T.; Palmer, D.H.; Neoptolemos, J.P. Chemotherapy for pancreatic cancer. Presse Med. 2019, 48, e159-e174. [CrossRef]

19. Zijlstra, M.; Bernards, N.; de Hingh, I.H.; van de Wouw, A.J.; Goey, S.H.; Jacobs, E.M.; Lemmens, V.E.; Creemers, G.J. Does long-term survival exist in pancreatic adenocarcinoma? Acta Oncol. 2016, 55, 259-264. [CrossRef]

20. Siegel, R.L.; Miller, K.D.; Jemal, A. Cancer statistics, 2018. CA Cancer J. Clin. 2018, 68, 7-30. [CrossRef]

21. Paulson, A.S.; Tran Cao, H.S.; Tempero, M.A.; Lowy, A.M. Therapeutic advances in pancreatic cancer. Gastroenterology 2013, 144, 1316-1326. [CrossRef] 
22. Wolff, R.A.; Chiao, P.; Lenzi, R.; Pisters, P.W.; Lee, J.E.; Janjan, N.A.; Crane, C.H.; Evans, D.B.; Abbruzzese, J.L. Current approaches and future strategies for pancreatic carcinoma. Investig. New Drugs 2000, 18, 43-56. [CrossRef]

23. Koay, E.J.; Truty, M.J.; Cristini, V.; Thomas, R.M.; Chen, R.; Chatterjee, D.; Kang, Y.; Bhosale, P.R.; Tamm, E.P.; Crane, C.H.; et al. Transport properties of pancreatic cancer describe gemcitabine delivery and response. J. Clin. Investig. 2014, 124, 1525-1536. [CrossRef]

24. Olive, K.P.; Jacobetz, M.A.; Davidson, C.J.; Gopinathan, A.; McIntyre, D.; Honess, D.; Madhu, B.; Goldgraben, M.A.; Caldwell, M.E.; Allard, D.; et al. Inhibition of Hedgehog signaling enhances delivery of chemotherapy in a mouse model of pancreatic cancer. Science 2009, 324, 1457-1461. [CrossRef]

25. Hung, S.W.; Mody, H.R.; Govindarajan, R. Overcoming nucleoside analog chemoresistance of pancreatic cancer: A therapeutic challenge. Cancer Lett. 2012, 320, 138-149. [CrossRef]

26. Liang, C.; Shi, S.; Meng, Q.; Liang, D.; Ji, S.; Zhang, B.; Qin, Y.; Xu, J.; Ni, Q.; Yu, X. Do anti-stroma therapies improve extrinsic resistance to increase the efficacy of gemcitabine in pancreatic cancer? Cell. Mol. Life Sci. 2018, 75, 1001-1012. [CrossRef] [PubMed]

27. Ju, H.Q.; Gocho, T.; Aguilar, M.; Wu, M.; Zhuang, Z.N.; Fu, J.; Yanaga, K.; Huang, P.; Chiao, P.J. Mechanisms of Overcoming Intrinsic Resistance to Gemcitabine in Pancreatic Ductal Adenocarcinoma through the Redox Modulation. Mol. Cancer Ther. 2015, 14, 788-798. [CrossRef]

28. Mini, E.; Nobili, S.; Caciagli, B.; Landini, I.; Mazzei, T. Cellular pharmacology of gemcitabine. Ann. Oncol. 2006, 17 (Suppl. S5), v7-v12. [CrossRef] [PubMed]

29. Binenbaum, Y.; Na'ara, S.; Gil, Z. Gemcitabine resistance in pancreatic ductal adenocarcinoma. Drug Resist. Updates 2015, 23, 55-68. [CrossRef] [PubMed]

30. Amrutkar, M.; Gladhaug, I.P. Pancreatic Cancer Chemoresistance to Gemcitabine. Cancers 2017, 9, 157. [CrossRef]

31. Apte, M.V.; Park, S.; Phillips, P.A.; Santucci, N.; Goldstein, D.; Kumar, R.K.; Ramm, G.A.; Buchler, M.; Friess, H.; McCarroll, J.A.; et al. Desmoplastic reaction in pancreatic cancer: Role of pancreatic stellate cells. Pancreas 2004, 29, 179-187. [CrossRef]

32. Neesse, A.; Algül, H.; Tuveson, D.A.; Gress, T.M. Stromal biology and therapy in pancreatic cancer: A changing paradigm. Gut 2015, 64, 1476-1484. [CrossRef] [PubMed]

33. Dauer, P.; Zhao, X.; Gupta, V.K.; Sharma, N.; Kesh, K.; Gnamlin, P.; Dudeja, V.; Vickers, S.M.; Banerjee, S.; Saluja, A. Inactivation of Cancer-Associated-Fibroblasts Disrupts Oncogenic Signaling in Pancreatic Cancer Cells and Promotes Its Regression. Cancer Res. 2018, 78, 1321-1333. [CrossRef] [PubMed]

34. Mahadevan, D.; Von Hoff, D.D. Tumor-stroma interactions in pancreatic ductal adenocarcinoma. Mol. Cancer Ther. 2007, 6, 1186-1197. [CrossRef] [PubMed]

35. Liang, C.; Shi, S.; Meng, Q.; Liang, D.; Ji, S.; Zhang, B.; Qin, Y.; Xu, J.; Ni, Q.; Yu, X. Complex roles of the stroma in the intrinsic resistance to gemcitabine in pancreatic cancer: Where we are and where we are going. Exp. Mol. Med. 2017, 49, e406. [CrossRef]

36. Ng, S.S.W.; Tsao, M.S.; Chow, S.; Hedley, D.W. Inhibition of phosphatidylinositide 3-kinase enhances gemcitabine-induced apoptosis in human pancreatic cancer cells. Cancer Res. 2000, 60, 5451-5455.

37. Yoon, H.; Min, J.K.; Lee, J.W.; Kim, D.G.; Hong, H.J. Acquisition of chemoresistance in intrahepatic cholangiocarcinoma cells by activation of AKT and extracellular signal-regulated kinase (ERK)1/2. Biochem. Biophys. Res. Commun. 2011, 405, 333-337. [CrossRef]

38. Liang, K.; Lu, Y.; Li, X.; Zeng, X.; Glazer, R.I.; Mills, G.B.; Fan, Z. Differential roles of phosphoinositide-dependent protein kinase-1 and akt1 expression and phosphorylation in breast cancer cell resistance to Paclitaxel, Doxorubicin, and gemcitabine. Mol. Pharm. 2006, 70, 1045-1052. [CrossRef]

39. Mu, G.G.; Zhang, L.L.; Li, H.Y.; Liao, Y.; Yu, H.G. Thymoquinone Pretreatment Overcomes the Insensitivity and Potentiates the Antitumor Effect of Gemcitabine Through Abrogation of Notch1, PI3K/Akt/mTOR Regulated Signaling Pathways in Pancreatic Cancer. Dig. Dis. Sci. 2015, 60, 1067-1080. [CrossRef]

40. Zhou, W.; Fu, X.Q.; Zhang, L.L.; Zhang, J.; Huang, X.; Lu, X.H.; Shen, L.; Liu, B.N.; Liu, J.; Luo, H.S.; et al. The AKT1/NFkappaB/Notch1/PTEN axis has an important role in chemoresistance of gastric cancer cells. Cell Death Dis. 2013,4 , e847. [CrossRef]

41. Whelan, J.T.; Kellogg, A.; Shewchuk, B.M.; Hewan-Lowe, K.; Bertrand, F.E. Notch-1 signaling is lost in prostate adenocarcinoma and promotes PTEN gene expression. J. Cell. Biochem. 2009, 107, 992-1001. [CrossRef]

42. Zhang, Y.; Zhang, J.; Xu, K.; Xiao, Z.; Sun, J.; Xu, J.; Wang, J.; Tang, Q. PTEN/PI3K/mTOR/B7-H1 signaling pathway regulates cell progression and immuno-resistance in pancreatic cancer. Hepatogastroenterology 2013, 60, 1766-1772.

43. Arafa el, S.A.; Zhu, Q.; Shah, Z.I.; Wani, G.; Barakat, B.M.; Racoma, I.; El-Mahdy, M.A.; Wani, A.A. Thymoquinone up-regulates PTEN expression and induces apoptosis in doxorubicin-resistant human breast cancer cells. Mutat. Res. 2011, 706, 28-35. [CrossRef]

44. Giroux, V.; Iovanna, J.; Dagorn, J.C. Probing the human kinome for kinases involved in pancreatic cancer cell survival and gemcitabine resistance. FASEB J. 2006, 20, 1982-1991. [CrossRef] [PubMed]

45. Akada, M.; Crnogorac-Jurcevic, T.; Lattimore, S.; Mahon, P.; Lopes, R.; Sunamura, M.; Matsuno, S.; Lemoine, N.R. Intrinsic chemoresistance to gemcitabine is associated with decreased expression of BNIP3 in pancreatic cancer. Clin. Cancer Res. 2005, 11, 3094-3101. [CrossRef] 
46. Habiro, A.; Tanno, S.; Koizumi, K.; Izawa, T.; Nakano, Y.; Osanai, M.; Mizukami, Y.; Okumura, T.; Kohgo, Y. Involvement of p38 mitogen-activated protein kinase in gemcitabine-induced apoptosis in human pancreatic cancer cells. Biochem. Biophys. Res. Commun. 2004, 316, 71-77. [CrossRef]

47. Gao, H.; Bai, Y.; Jia, Y.; Zhao, Y.; Kang, R.; Tang, D.; Dai, E. Ferroptosis is a lysosomal cell death process. Biochem. Biophys. Res. Commun. 2018, 503, 1550-1556. [CrossRef]

48. Hattori, K.; Ishikawa, H.; Sakauchi, C.; Takayanagi, S.; Naguro, I.; Ichijo, H. Cold stress-induced ferroptosis involves the ASK1-p38 pathway. EMBO Rep. 2017, 18, 2067-2078. [CrossRef] [PubMed]

49. Hernández-Vargas, H.; Rodríguez-Pinilla, S.M.; Julián-Tendero, M.; Sánchez-Rovira, P.; Cuevas, C.; Antón, A.; Ríos, M.J.; Palacios, J.; Moreno-Bueno, G. Gene expression profiling of breast cancer cells in response to gemcitabine: NF-kappaB pathway activation as a potential mechanism of resistance. Breast Cancer Res. Treat. 2007, 102, 157-172. [CrossRef] [PubMed]

50. Guo, X.; Xu, B.; Pandey, S.; Goessl, E.; Brown, J.; Armesilla, A.L.; Darling, J.L.; Wang, W. Disulfiram/copper complex inhibiting NFkappaB activity and potentiating cytotoxic effect of gemcitabine on colon and breast cancer cell lines. Cancer Lett. 2010, 290, 104-113. [CrossRef] [PubMed]

51. Arora, S.; Bhardwaj, A.; Singh, S.; Srivastava, S.K.; McClellan, S.; Nirodi, C.S.; Piazza, G.A.; Grizzle, W.E.; Owen, L.B.; Singh, A.P. An undesired effect of chemotherapy: Gemcitabine promotes pancreatic cancer cell invasiveness through reactive oxygen species-dependent, nuclear factor kB- and hypoxia-inducible factor $1 \alpha$-mediated up-regulation of CXCR4. J. Biol. Chem. 2013, 288, 21197-21207. [CrossRef] [PubMed]

52. Denlinger, C.E.; Rundall, B.K.; Keller, M.D.; Jones, D.R. Proteasome inhibition sensitizes non-small-cell lung cancer to gemcitabineinduced apoptosis. Ann. Thorac. Surg. 2004, 78, 1207-1214. [CrossRef]

53. Arlt, A.; Gehrz, A.; Müerköster, S.; Vorndamm, J.; Kruse, M.L.; Fölsch, U.R.; Schäfer, H. Role of NF-kappaB and Akt/PI3K in the resistance of pancreatic carcinoma cell lines against gemcitabine-induced cell death. Oncogene 2003, 22, 3243-3251. [CrossRef]

54. Li, Q.; Yang, G.; Feng, M.; Zheng, S.; Cao, Z.; Qiu, J.; You, L.; Zheng, L.; Hu, Y.; Zhang, T.; et al. NF-kB in pancreatic cancer: Its key role in chemoresistance. Cancer Lett. 2018, 421, 127-134. [CrossRef]

55. Arlt, A.; Schäfer, H.; Kalthoff, H. The 'N-factors' in pancreatic cancer: Functional relevance of NF-kB, NFAT and Nrf2 in pancreatic cancer. Oncogenesis 2012, 1, e35. [CrossRef]

56. Mitsuishi, Y.; Motohashi, H.; Yamamoto, M. The Keap1-Nrf2 system in cancers: Stress response and anabolic metabolism. Front. Oncol. 2012, 2, 200. [CrossRef] [PubMed]

57. Hong, Y.B.; Kang, H.J.; Kwon, S.Y.; Kim, H.J.; Kwon, K.Y.; Cho, C.H.; Lee, J.M.; Kallakury, B.V.; Bae, I. Nuclear factor (erythroidderived 2)-like 2 regulates drug resistance in pancreatic cancer cells. Pancreas 2010, 39, 463-472. [CrossRef]

58. Homma, S.; Ishii, Y.; Morishima, Y.; Yamadori, T.; Matsuno, Y.; Haraguchi, N.; Kikuchi, N.; Satoh, H.; Sakamoto, T.; Hizawa, N.; et al. Nrf2 enhances cell proliferation and resistance to anticancer drugs in human lung cancer. Clin. Cancer Res. 2009, 15, 3423-3432. [CrossRef]

59. Hartikainen, J.M.; Tengström, M.; Kosma, V.M.; Kinnula, V.L.; Mannermaa, A.; Soini, Y. Genetic polymorphisms and protein expression of NRF2 and Sulfiredoxin predict survival outcomes in breast cancer. Cancer Res. 2012, 72, 5537-5546. [CrossRef] [PubMed]

60. Zheng, H.; Nong, Z.; Lu, G. Correlation Between Nuclear Factor E2-Related Factor 2 Expression and Gastric Cancer Progression. Med. Sci. Monit. 2015, 21, 2893-2899. [CrossRef]

61. Zhou, Y.; Wang, K.; Zhou, Y.; Li, T.; Yang, M.; Wang, R.; Chen, Y.; Cao, M.; Hu, R. HEATR1 deficiency promotes pancreatic cancer proliferation and gemcitabine resistance by up-regulating Nrf2 signaling. Redox Biol. 2020, 29, 101390. [CrossRef]

62. Zhou, Y.; Zhou, Y.; Yang, M.; Wang, K.; Liu, Y.; Zhang, M.; Yang, Y.; Jin, C.; Wang, R.; Hu, R. Digoxin sensitizes gemcitabineresistant pancreatic cancer cells to gemcitabine via inhibiting Nrf2 signaling pathway. Redox Biol. 2019, 22, 101131. [CrossRef]

63. Duong, H.Q.; Yi, Y.W.; Kang, H.J.; Hong, Y.B.; Tang, W.; Wang, A.; Seong, Y.S.; Bae, I. Inhibition of NRF2 by PIK-75 augments sensitivity of pancreatic cancer cells to gemcitabine. Int. J. Oncol. 2014, 44, 959-969. [CrossRef] [PubMed]

64. Zhang, H.; Trachootham, D.; Lu, W.; Carew, J.; Giles, F.J.; Keating, M.J.; Arlinghaus, R.B.; Huang, P. Effective killing of Gleevecresistant CML cells with T315I mutation by a natural compound PEITC through redox-mediated mechanism. Leukemia 2008, 22, 1191-1199. [CrossRef] [PubMed]

65. Hu, Y.; Lu, W.; Chen, G.; Zhang, H.; Jia, Y.; Wei, Y.; Yang, H.; Zhang, W.; Fiskus, W.; Bhalla, K.; et al. Overcoming resistance to histone deacetylase inhibitors in human leukemia with the redox modulating compound $\beta$-phenylethyl isothiocyanate. Blood 2010, 116, 2732-2741. [CrossRef]

66. Dubrez, L.; Causse, S.; Borges Bonan, N.; Dumétier, B.; Garrido, C. Heat-shock proteins: Chaperoning DNA repair. Oncogene 2020, 39, 516-529. [CrossRef] [PubMed]

67. Ghadban, T.; Dibbern, J.; Reeh, M.; Miro, J.; Tsui, T.; Wellner, U.; Izbicki, J.; Güngör, C.; Vashist, Y.K. HSP90 is a promising target in gemcitabine and 5-fluorouracil resistant pancreatic cancer. Apoptosis 2017, 22, 369-380. [CrossRef]

68. Sliutz, G.; Karlseder, J.; Tempfer, C.; Orel, L.; Holzer, G.; Simon, M.M. Drug resistance against gemcitabine and topotecan mediated by constitutive hsp70 overexpression in vitro: Implication of quercetin as sensitiser in chemotherapy. Br. J. Cancer 1996, 74, 172-177. [CrossRef]

69. Hyun, J.J.; Lee, H.S.; Keum, B.; Seo, Y.S.; Jeen, Y.T.; Chun, H.J.; Um, S.H.; Kim, C.D. Expression of heat shock protein 70 modulates the chemoresponsiveness of pancreatic cancer. Gut Liver 2013, 7, 739-746. [CrossRef] 
70. Mori-Iwamoto, S.; Kuramitsu, Y.; Ryozawa, S.; Mikuria, K.; Fujimoto, M.; Maehara, S.; Maehara, Y.; Okita, K.; Nakamura, K.; Sakaida, I. Proteomics finding heat shock protein 27 as a biomarker for resistance of pancreatic cancer cells to gemcitabine. Int. J. Oncol. 2007, 31, 1345-1350. [CrossRef]

71. Kuramitsu, Y.; Taba, K.; Ryozawa, S.; Yoshida, K.; Zhang, X.; Tanaka, T.; Maehara, S.; Maehara, Y.; Sakaida, I.; Nakamura, K. Identification of up- and down-regulated proteins in gemcitabine-resistant pancreatic cancer cells using two-dimensional gel electrophoresis and mass spectrometry. Anticancer Res. 2010, 30, 3367-3372.

72. Mori-Iwamoto, S.; Kuramitsu, Y.; Ryozawa, S.; Taba, K.; Fujimoto, M.; Okita, K.; Nakamura, K.; Sakaida, I. A proteomic profiling of gemcitabine resistance in pancreatic cancer cell lines. Mol. Med. Rep. 2008, 1, 429-434. [CrossRef]

73. Kozinn, S.I.; Harty, N.J.; Delong, J.M.; Deliyiannis, C.; Logvinenko, T.; Summerhayes, I.C.; Libertino, J.A.; Holway, A.H.; RiegerChrist, K.M. MicroRNA Profile to Predict Gemcitabine Resistance in Bladder Carcinoma Cell Lines. Genes Cancer 2013, 4, 61-69. [CrossRef]

74. Li, H.; Yang, B.B. Friend or foe: The role of microRNA in chemotherapy resistance. Acta Pharm. Sin. 2013, 34, 870-879. [CrossRef]

75. Drakaki, A.; Iliopoulos, D. MicroRNA-gene signaling pathways in pancreatic cancer. Biomed. J. 2013, 36, 200-208. [CrossRef] [PubMed]

76. Xia, X.; Zhang, K.; Luo, G.; Cen, G.; Cao, J.; Huang, K.; Qiu, Z. Downregulation of miR-301a-3p sensitizes pancreatic cancer cells to gemcitabine treatment via PTEN. Am. J. Transl. Res. 2017, 9, 1886-1895. [PubMed]

77. Fang, Y.; Zhou, W.; Rong, Y.; Kuang, T.; Xu, X.; Wu, W.; Wang, D.; Lou, W. Exosomal miRNA-106b from cancer-associated fibroblast promotes gemcitabine resistance in pancreatic cancer. Exp. Cell Res. 2019, 383, 111543. [CrossRef] [PubMed]

78. Wei, F.; Ma, C.; Zhou, T.; Dong, X.; Luo, Q.; Geng, L.; Ding, L.; Zhang, Y.; Zhang, L.; Li, N.; et al. Exosomes derived from gemcitabine-resistant cells transfer malignant phenotypic traits via delivery of miRNA-222-3p. Mol. Cancer 2017, 16, 132. [CrossRef] [PubMed]

79. Hamada, S.; Masamune, A.; Miura, S.; Satoh, K.; Shimosegawa, T. MiR-365 induces gemcitabine resistance in pancreatic cancer cells by targeting the adaptor protein SHC1 and pro-apoptotic regulator BAX. Cell Signal. 2014, 26, 179-185. [CrossRef] [PubMed]

80. Li, Y.; VandenBoom, T.G., 2nd; Kong, D.; Wang, Z.; Ali, S.; Philip, P.A.; Sarkar, F.H. Up-regulation of miR-200 and let-7 by natural agents leads to the reversal of epithelial-to-mesenchymal transition in gemcitabine-resistant pancreatic cancer cells. Cancer Res. 2009, 69, 6704-6712. [CrossRef] [PubMed]

81. Li, J.; Wu, H.; Li, W.; Yin, L.; Guo, S.; Xu, X.; Ouyang, Y.; Zhao, Z.; Liu, S.; Tian, Y.; et al. Downregulated miR-506 expression facilitates pancreatic cancer progression and chemoresistance via SPHK1/Akt/NF-kB signaling. Oncogene 2016, 35, 5501-5514. [CrossRef]

82. Dixon, S.J.; Stockwell, B.R. The role of iron and reactive oxygen species in cell death. Nat. Chem. Biol. 2014, 10, 9-17. [CrossRef]

83. Chen, X.; Zeh, H.J.; Kang, R.; Kroemer, G.; Tang, D. Cell death in pancreatic cancer: From pathogenesis to therapy. Nat. Rev. Gastroenterol. Hepatol. 2021. [CrossRef]

84. Kazan, H.H.; Urfali-Mamatoglu, C.; Gunduz, U. Iron metabolism and drug resistance in cancer. Biometals 2017, 30, 629-641. [CrossRef]

85. Torti, S.V.; Torti, F.M. Cellular iron metabolism in prognosis and therapy of breast cancer. Crit. Rev. Oncog. 2013, 18, 435-448. [CrossRef] [PubMed]

86. Richardson, D.R.; Kalinowski, D.S.; Lau, S.; Jansson, P.J.; Lovejoy, D.B. Cancer cell iron metabolism and the development of potent iron chelators as anti-tumour agents. Biochim. Biophys. Acta 2009, 1790, 702-717. [CrossRef] [PubMed]

87. Torti, S.V.; Torti, F.M. Ironing out cancer. Cancer Res. 2011, 71, 1511-1514. [CrossRef] [PubMed]

88. Torti, S.V.; Torti, F.M. Iron and cancer: More ore to be mined. Nat. Rev. Cancer 2013, 13, 342-355. [CrossRef]

89. Latunde-Dada, G.O. Ferroptosis: Role of lipid peroxidation, iron and ferritinophagy. Biochim. Biophys. Acta Gen. Subj. 2017, 1861, 1893-1900. [CrossRef]

90. Dolma, S.; Lessnick, S.L.; Hahn, W.C.; Stockwell, B.R. Identification of genotype-selective antitumor agents using synthetic lethal chemical screening in engineered human tumor cells. Cancer Cell 2003, 3, 285-296. [CrossRef]

91. Cao, J.Y.; Dixon, S.J. Mechanisms of ferroptosis. Cell. Mol. Life Sci. 2016, 73, 2195-2209. [CrossRef] [PubMed]

92. Yang, W.S.; SriRamaratnam, R.; Welsch, M.E.; Shimada, K.; Skouta, R.; Viswanathan, V.S.; Cheah, J.H.; Clemons, P.A.; Shamji, A.F.; Clish, C.B.; et al. Regulation of ferroptotic cancer cell death by GPX4. Cell 2014, 156, 317-331. [CrossRef] [PubMed]

93. Dai, E.; Han, L.; Liu, J.; Xie, Y.; Zeh, H.J.; Kang, R.; Bai, L.; Tang, D. Ferroptotic damage promotes pancreatic tumorigenesis through a TMEM173/STING-dependent DNA sensor pathway. Nat. Commun. 2020, 11, 6339. [CrossRef] [PubMed]

94. Seiler, A.; Schneider, M.; Förster, H.; Roth, S.; Wirth, E.K.; Culmsee, C.; Plesnila, N.; Kremmer, E.; Rådmark, O.; Wurst, W.; et al. Glutathione peroxidase 4 senses and translates oxidative stress into 12/15-lipoxygenase dependent- and AIF-mediated cell death. Cell Metab. 2008, 8, 237-248. [CrossRef] [PubMed]

95. Lee, J.W.; Komar, C.A.; Bengsch, F.; Graham, K.; Beatty, G.L. Genetically Engineered Mouse Models of Pancreatic Cancer: The KPC Model (LSL-Kras ${ }^{\mathrm{G} 12 \mathrm{D} /+}$; LSL-Trp53 ${ }^{\mathrm{R} 172 \mathrm{H} /+}$; Pdx-1-Cre), Its Variants, and Their Application in Immuno-oncology Drug Discovery. Curr. Protoc. Pharmacol. 2016, 73, 14.39.11-14.39.20. [CrossRef]

96. Badgley, M.A.; Kremer, D.M.; Maurer, H.C.; DelGiorno, K.E.; Lee, H.J.; Purohit, V.; Sagalovskiy, I.R.; Ma, A.; Kapilian, J.; Firl, C.E.M.; et al. Cysteine depletion induces pancreatic tumor ferroptosis in mice. Science 2020, 368, 85-89. [CrossRef] 
97. Zhang, Y.; Yan, W.; Collins, M.A.; Bednar, F.; Rakshit, S.; Zetter, B.R.; Stanger, B.Z.; Chung, I.; Rhim, A.D.; di Magliano, M.P. Interleukin-6 is required for pancreatic cancer progression by promoting MAPK signaling activation and oxidative stress resistance. Cancer Res. 2013, 73, 6359-6374. [CrossRef]

98. Li, C.; Zhang, Y.; Liu, J.; Kang, R.; Klionsky, D.J.; Tang, D. Mitochondrial DNA stress triggers autophagy-dependent ferroptotic death. Autophagy 2021, 17, 948-960. [CrossRef]

99. Li, C.; Liu, J.; Hou, W.; Kang, R.; Tang, D. STING1 Promotes Ferroptosis Through MFN1/2-Dependent Mitochondrial Fusion. Front. Cell Dev. Biol. 2021, 9, 698679. [CrossRef]

100. Kremer, D.M.; Nelson, B.S.; Lin, L.; Yarosz, E.L.; Halbrook, C.J.; Kerk, S.A.; Sajjakulnukit, P.; Myers, A.; Thurston, G.; Hou, S.W.; et al. GOT1 inhibition promotes pancreatic cancer cell death by ferroptosis. Nat. Commun. 2021, 12, 4860. [CrossRef]

101. Sun, X.; Niu, X.; Chen, R.; He, W.; Chen, D.; Kang, R.; Tang, D. Metallothionein-1G facilitates sorafenib resistance through inhibition of ferroptosis. Hepatology 2016, 64, 488-500. [CrossRef]

102. Sun, X.; Ou, Z.; Chen, R.; Niu, X.; Chen, D.; Kang, R.; Tang, D. Activation of the p62-Keap1-NRF2 pathway protects against ferroptosis in hepatocellular carcinoma cells. Hepatology 2016, 63, 173-184. [CrossRef]

103. Louandre, C.; Ezzoukhry, Z.; Godin, C.; Barbare, J.C.; Mazière, J.C.; Chauffert, B.; Galmiche, A. Iron-dependent cell death of hepatocellular carcinoma cells exposed to sorafenib. Int. J. Cancer 2013, 133, 1732-1742. [CrossRef]

104. Galmiche, A.; Chauffert, B.; Barbare, J.C. New biological perspectives for the improvement of the efficacy of sorafenib in hepatocellular carcinoma. Cancer Lett. 2014, 346, 159-162. [CrossRef]

105. Chou, T.C. Drug combination studies and their synergy quantification using the Chou-Talalay method. Cancer Res. 2010, 70, 440-446. [CrossRef]

106. Gao, M.; Monian, P.; Quadri, N.; Ramasamy, R.; Jiang, X. Glutaminolysis and Transferrin Regulate Ferroptosis. Mol. Cell 2015, 59, 298-308. [CrossRef]

107. Donadelli, M.; Costanzo, C.; Beghelli, S.; Scupoli, M.T.; Dandrea, M.; Bonora, A.; Piacentini, P.; Budillon, A.; Caraglia, M.; Scarpa, A.; et al. Synergistic inhibition of pancreatic adenocarcinoma cell growth by trichostatin A and gemcitabine. Biochim. Biophys. Acta 2007, 1773, 1095-1106. [CrossRef]

108. Trachootham, D.; Alexandre, J.; Huang, P. Targeting cancer cells by ROS-mediated mechanisms: A radical therapeutic approach? Nat. Rev. Drug Discov. 2009, 8, 579-591. [CrossRef]

109. Trachootham, D.; Lu, W.; Ogasawara, M.A.; Nilsa, R.D.; Huang, P. Redox regulation of cell survival. Antioxid. Redox Signal. 2008, 10, 1343-1374. [CrossRef]

110. Lau, A.; Villeneuve, N.F.; Sun, Z.; Wong, P.K.; Zhang, D.D. Dual roles of Nrf2 in cancer. Pharm. Res 2008, 58, 262-270. [CrossRef]

111. Manea, A.; Manea, S.A.; Gafencu, A.V.; Raicu, M. Regulation of NADPH oxidase subunit p22(phox) by NF-kB in human aortic smooth muscle cells. Arch. Physiol. Biochem. 2007, 113, 163-172. [CrossRef]

112. Lister, A.; Nedjadi, T.; Kitteringham, N.R.; Campbell, F.; Costello, E.; Lloyd, B.; Copple, I.M.; Williams, S.; Owen, A.; Neoptolemos, J.P.; et al. Nrf2 is overexpressed in pancreatic cancer: Implications for cell proliferation and therapy. Mol. Cancer 2011, 10, 37. [CrossRef] [PubMed]

113. Sporn, M.B.; Liby, K.T. NRF2 and cancer: The good, the bad and the importance of context. Nat. Rev. Cancer 2012, $12,564-571$. [CrossRef]

114. Gorrini, C.; Harris, I.S.; Mak, T.W. Modulation of oxidative stress as an anticancer strategy. Nat. Rev. Drug Discov. 2013, 12, 931-947. [CrossRef]

115. Roh, J.L.; Kim, E.H.; Jang, H.; Shin, D. Nrf2 inhibition reverses the resistance of cisplatin-resistant head and neck cancer cells to artesunate-induced ferroptosis. Redox Biol. 2017, 11, 254-262. [CrossRef]

116. Fan, Z.; Wirth, A.K.; Chen, D.; Wruck, C.J.; Rauh, M.; Buchfelder, M.; Savaskan, N. Nrf2-Keap1 pathway promotes cell proliferation and diminishes ferroptosis. Oncogenesis 2017, 6, e371. [CrossRef]

117. Li-Weber, M. New therapeutic aspects of flavones: The anticancer properties of Scutellaria and its main active constituents Wogonin, Baicalein and Baicalin. Cancer Treat. Rev. 2009, 35, 57-68. [CrossRef]

118. Xie, Y.; Song, X.; Sun, X.; Huang, J.; Zhong, M.; Lotze, M.T.; Zeh, H.J.R.; Kang, R.; Tang, D. Identification of baicalein as a ferroptosis inhibitor by natural product library screening. Biochem. Biophys. Res. Commun. 2016, 473, 775-780. [CrossRef]

119. Dodson, M.; Castro-Portuguez, R.; Zhang, D.D. NRF2 plays a critical role in mitigating lipid peroxidation and ferroptosis. Redox Biol. 2019, 23, 101107. [CrossRef] [PubMed]

120. Kumar, N.; Perez-Novo, C.; Shaw, P.; Logie, E.; Privat-Maldonado, A.; Dewilde, S.; Smits, E.; Vanden Berghe, W.; Bogaerts, A. Physical plasma-derived oxidants sensitize pancreatic cancer cells to ferroptotic cell death. Free Radic. Biol. Med. 2021, 166, 187-200. [CrossRef] [PubMed]

121. Sun, X.; Ou, Z.; Xie, M.; Kang, R.; Fan, Y.; Niu, X.; Wang, H.; Cao, L.; Tang, D. HSPB1 as a novel regulator of ferroptotic cancer cell death. Oncogene 2015, 34, 5617-5625. [CrossRef] [PubMed]

122. $\mathrm{Wu}, \mathrm{C}$. Heat shock transcription factors: Structure and regulation. Annu. Rev. Cell Dev. Biol. 1995, 11, 441-469. [CrossRef] [PubMed]

123. Lee, A.S. Glucose-regulated proteins in cancer: Molecular mechanisms and therapeutic potential. Nat. Rev. Cancer 2014, 14, 263-276. [CrossRef] [PubMed]

124. Hetz, C. The unfolded protein response: Controlling cell fate decisions under ER stress and beyond. Nat. Rev. Mol. Cell Biol. 2012, 13, 89-102. [CrossRef] 
125. Zhu, S.; Zhang, Q.; Sun, X.; Zeh, H.J., 3rd; Lotze, M.T.; Kang, R.; Tang, D. HSPA5 Regulates Ferroptotic Cell Death in Cancer Cells. Cancer Res. 2017, 77, 2064-2077. [CrossRef]

126. Niu, Z.; Wang, M.; Zhou, L.; Yao, L.; Liao, Q.; Zhao, Y. Elevated GRP78 expression is associated with poor prognosis in patients with pancreatic cancer. Sci. Rep. 2015, 5, 16067. [CrossRef]

127. Daher, B.; Parks, S.K.; Durivault, J.; Cormerais, Y.; Baidarjad, H.; Tambutte, E.; Pouysségur, J.; Vučetić, M. Genetic Ablation of the Cystine Transporter xCT in PDAC Cells Inhibits mTORC1, Growth, Survival, and Tumor Formation via Nutrient and Oxidative Stresses. Cancer Res. 2019, 79, 3877-3890. [CrossRef]

128. Ye, Z.; Zhuo, Q.; Hu, Q.; Xu, X.; Mengqi, L.; Zhang, Z.; Xu, W.; Liu, W.; Fan, G.; Qin, Y.; et al. FBW7-NRA41-SCD1 axis synchronously regulates apoptosis and ferroptosis in pancreatic cancer cells. Redox Biol. 2021, 38, 101807. [CrossRef]

129. Ye, M.; Zhang, Y.; Zhang, X.; Zhang, J.; Jing, P.; Cao, L.; Li, N.; Li, X.; Yao, L.; Zhang, J.; et al. Targeting FBW7 as a Strategy to Overcome Resistance to Targeted Therapy in Non-Small Cell Lung Cancer. Cancer Res. 2017, 77, 3527-3539. [CrossRef]

130. Gao, J.; Zhang, Z.; Liu, Y.; Zhang, Z.; Wang, M.; Gong, A.; Xia, L.; Liao, X.; Wang, D.; Zhu, H. Stearoyl-CoA Desaturase 1 Potentiates Hypoxic plus Nutrient-Deprived Pancreatic Cancer Cell Ferroptosis Resistance. Oxidative Med. Cell. Longev. 2021, 2021, 6629804. [CrossRef] [PubMed]

131. Yang, J.C.; Ding, L.; Yu, L.D.; Wang, Y.M.; Ge, M.; Jiang, Q.Z.; Chen, Y. Nanomedicine enables autophagy-enhanced cancer-cell ferroptosis. Sci. Bull. 2021, 66, 464-477. [CrossRef] 